Relations industrielles

Industrial Relations

\title{
Strauss, George, Daniel Gallagher, and Jack Fiorito, eds., The State of the Unions
}

\section{Clive H.J. Gilson}

Volume 48, numéro 1, 1993

URI : https://id.erudit.org/iderudit/050842ar

DOI : https://doi.org/10.7202/050842ar

Aller au sommaire du numéro

Éditeur(s)

Département des relations industrielles de l'Université Laval

ISSN

0034-379X (imprimé)

1703-8138 (numérique)

Découvrir la revue

Citer ce compte rendu

Gilson, C. H. (1993). Compte rendu de [Strauss, George, Daniel Gallagher, and Jack Fiorito, eds., The State of the Unions]. Relations industrielles / Industrial Relations, 48(1), 195-198. https://doi.org/10.7202/050842ar

Tous droits réservés (C) Département des relations industrielles de l'Université Laval, 1993
Ce document est protégé par la loi sur le droit d'auteur. L’utilisation des services d'Érudit (y compris la reproduction) est assujettie à sa politique d'utilisation que vous pouvez consulter en ligne.

https://apropos.erudit.org/fr/usagers/politique-dutilisation/ 
successfully analyze and measure the notion of national models of industrial relations and the role of employers in their development. Most of the contributions still seem to move unsteadily and rapidly from the very generalized statements about employers and industrial relations through to outlining highly specific case studies. New approaches that can effectively posit and analyze international and comparative industrial relations at the intermediate-level still seem to be lacking. For example, Locke has recently argued that the strategic choices of employers and trade unions lead to outcomes which challenge the concept of national industrial relations. He suggests that the diversity within industrial relations systems will, in certain industries or sectors, be greater than the diversity across systems. (R. Locke, "The Demise of the National Union in Italy", Industrial and Labor Relations Review, Vol. 45, No. 2, 1992, 229-249). However, as Tolliday and Zeitlin in the final chapter in this volume conclude, national models of industrial relations "should be understood not as homeostatic and self-producing systems of action but as complex and contingent historical constructions whose unity and coherence always remain open empirical questions"' (p. 277). Thus the comparative experiences of the empirical research in this book may portend the emergence of industrial relations in which various institutional arrangements are in a state of continuing evolution.

Overall the standard of the contributions are high, the book is very well referenced and presented, and at the level of editors' commentary it is extremely valuable. In addition, the volume is set out in a form which should be accessible to a wide range of social scientists interested in the determinants of employers' labour policies and their contribution to diverging (or converging) national patterns of industrial relations. The editors should be congratulated on their efforts and level of scholarship.

Anthony E. SMITH

University of New Brunswick

The State of the Unions, by George STRAuss, Daniel GallaGHER and Jack Fiorito, eds., Industrial Relations Research Association Series, 1991, 426 p., ISBN 0-913447-49-8, ISSN 50-13564, Lib. of Congress Catalog Card

Although the subject of union decline in the U.S. has taxed the research initiatives of industrial relations scholars for well over a decade now, this book probably stands as the most ambitious attempt to date to assess all the evidence. Strauss et al. have assembled an impressive volume here. We are presented with four parts which respectively dispense with the issues of Union Membership and Growth, Union Governance, Unions in Larger Perspective and The Future. Each section also includes further commentaries which embellish and interpret the main articles. And the editors' Preface also contains a meta-guide, thus helping the cursory reader to pick and choose from the menu. To carry out this task the editors claim to have "recruited a distinguished group of authors and commentators who represent a broad range of viewpoints, disciplines and ages" (p. vii), - a claim which is clearly legitimate. There is some dense yet valuable reading here. At least, at the level of institutional scholarship, little is missed and for that reason alone The State of the Unions will stand as a well thumbed reference resource. Nevertheless 
a collection such as this invariably carries with it some weaknesses and unevenness in quality.

Those authors whose contributions were designed to address either the historical basis of trade unionism or indeed, the present state of play, were able to effectively marshall some well argued conceptual and analytical maps. Later contributions which were required to do some fast extrapolation from existing trends, all in the hope of predicting the future, fared less well. This causes the book to move back and forth from solid analysis to prescription. Although the editors alert the reader to the practitioner value of the book, the consequences of trying to serve two masters cannot help but detract somewhat from the package.

More seriously, a book such as this, which inevitably concentrates upon union data, paradoxically spends much of its time looping in an out oxamining the impact of employer/management behaviour. Each of the chapters do this to some degree, but without systematic treatment our understanding of one of the most critical independent variables in understanding union decline remains incomplete. Thus we are denied a more dispassionate articulation of the role played by the "other side". Without proper development of this critical context we can rarely attain a sense of the relative significance of employer behaviour. Any further iterations of volumes such as this should contain a separate section on the impact of employer policies on unions.

Although it is beyond the scope of this review to critic every article (and to some degree unnecessary given the commentary already provided at the conclusion of each section), some reflection is in order. The opening chapter by Chaison and Rose, on the "Macrodeterminants of Union Growth and Decline", is simply outstanding. The reader is presented with a very thoughtful and careful review of the evidence regarding the cause(s) of declining union density. Indeed, the chapter almost takes on the air of a "whodunit' novel, with the reader anxiously waiting for the culprit to be revealed (the style is reminiscent of Goldfield's seminal contribution to this debate, in his book The Decline of Organized Labour in the United States 1987). And we are not disappointed. After warning us about the very real problems of actually measuring union membership Chaison and Rose thoroughly review all the independent variables which from time to time have been offered as explanations for the decline in trade unionism. Finally, it is revealed that a combination of anti-union public policies, refracted through various legal dimensions, together with increasing employer hostility and poor union organizing ability are the chief determinants of union decline. The analysis presented is buttressed considerably by the judicious use of comparative analysis with other countries. This also reveals that unions will likely do better when administrations are more supportive of labour organizing principles. Notwithstanding the complaints articulated by Troy, Canada is presented by the authors as a possible example of this phenomena. Finally, Chaison and Rose add credence to Bain and Price's notion of paradigmatic shifts whereby major changes in trade union membership are prefaced by a shift of the societal terrain. All other changes take place within unremarkable structural contexts. The question to be answered therefore is the extent to which the present decline in union membership represents a fundamental societal shift or a continued (if slow and inexorable) re-calibration of structural forces. 
In his commentary to this section of the book, Ronald Seeber offers a partial answer to this conundrum. He does this by way of heavily criticizing the second chapter, written by Wheeler and McClendon, who argue for the adoption of an "individual choice" model which suggests that the decision to join a trade union is an aggressive act which requires a combination of disaffection (Model A) and a search for utility or gain (Model B). Echoing Daniel Bell's historic announcement of almost a generation ago, of the 'End of Ideology', the authors reject an additional Model $\mathrm{C}$ which suggests that choices may also be based on (radical) political preference. Seeber reviews these models as simple (and tautological) taxonomies which vastly over-emphasise the significance of individual choices per se. He argues that disproportionate power in favour of employers effectively "washes out", pure rational choices made by individuals. This perspective is not too far away from a recognition that such an imbalance of power between unions and management can be characterized not just as a series of structural tremors, but as a fundamental rupture in the balance of class forces. Such a conclusion could easily be drawn from the data and interpretations which are offered by Chaison and Rose.

Part II of the book offers a pot-pourri of inter alia union democracy issues, union goals, strategies, choices of bargaining structure and the reasons behind the present morphology of union structure, i.e. the external contours of union jurisdiction. Read separately, there is much to be learned here, but in truth, this section of the book might have benefitted from some stiff editorial re-structuring into at least two parts rather than the one presented. Fiorito, Gramm and Hendricks argue that the nature of internal structure or governance will be largely determined by union choices regarding over-arching goals, strategy and preferred bargaining structure. Although the authors recognize the import of history and large-scale organizational inertia, these critical variables are not thoroughly worked into their model. This may well be a fatal blow if we accept from the previous section, that the power and real opportunity to make choices has long since departed. This leaves us, as Knight recognizes in his commentary with a classic dilemma for unions. On the one hand there are distinct pressures for union to centralize their processes in order to efficiently respond to the employers' onslanght to de-regulate the labour market. On the other hand, this will have the tendency to reduce the prospects of rank and file democracy as union officials struggle mightily impose standard rates and conditions against whipsawing. This perspective clearly and firmly places union choices regarding goals strategy and preferred bargaining structure within the context of historical, political and economic developments. These issues are also suitably addressed in Strauss's extensive survey chapter of the literature on union democracy.

In Part III, Brody offers an historical review of the Union in larger perspective, arguing that American workers and their unions have always organized around the notion of job consciousness. Moreover, Brody optimistically argues, using the Steel industry as exemplar, that despite considerable inroads into the union "method" of collective bargaining, the edifice of industrial relations processes remains largely intact. He goes on to argue that if what Barbash calls the New Industrial Relations, practised by management, fails to deliver justice and dignity in the workplace - worker aspirations will once again turn towards existing trade unions albeit in different guises. Barkin however, in his commentary, charts the continued "enfeeblement of the union 
movement" and appears to doubt the robustness of the existing leadership to tackle recessionary pressures. He also doubts its ability to transcend pure and simple unionism. This throws the spotlight upon unions and politics. Unfortunately, the relevant chapter by Delaney and Masters does not operate on a complementary level. We do learn that unions invariably involve themselves in politics to influence the legislative agenda, favourably towards union objectives, meaning their security and the continuation of collective bargaining. At this level, Delaney and Masters provide an excellent service in bringing together the existing literature. However, it might have been more useful to have the authors cast their net in wider terms, both conceptually and comparatively. We really need to know how union movements have responded at the aggregate level to the shifting fortunes of capital. A discussion of corporatism is desperately needed here. Comparative analysis of how British unions (the early versions of the Social Contract) and more recently, the Australian Accords between the ACTU and Labour administrations (now being dismantled) might have enabled us to appraise more usefully the relative strengths and weaknesses of U.S. unions in relation to their political agenda.

In the final segment on the future, articles by Kochan and Weaver and finally Piore, emphasise that unions must construct broader appeals if they are to remain important democratic institutions in American society. The former argue for increasing training and "upskilling" in order to make peripheral workers look more like the "core". Piore argues for further links with the marginalized sections of the labour force within the context of supportive local communities of interest. Hyman, in his commentary, applauds the value of constructing a broader structure of identities for unions but is less than convinced that success is forthcoming. His solution, as an avowed Marxist in the European tradition, is to place greater emphasise on the external origins of workplace antagonisms. He presumably feels that when workers recognise that it is the whims of short-term capital markets which cause their discontent, that internal sectional distinctions may be transcended. Put simply, Hyman is arguing that only when American unions recognise their broader class identity, will their fortunes and those of the working-class in general, improve.

An interesting conclusion indeed to a book typically cast in the traditions of American industrial relations orthodoxy.

Clive H. J. GilsoN

\section{St. Francis Xavier University}

Labour Arbitration in America, research conducted under the auspices of the National Academy of Arbitrators and the NAA Research and Education Foundation, New York, Praeger, 1992, 186 p., ISBN 0-275-94375-5

Cet ouvrage présente les résultats d'une recherche exhaustive menée aux ÉtatsUnis sur le profil des personnes agissant comme arbitre et sur les caractéristiques de leur pratique. La recherche a été dirigée par les professeurs Mario F. Bognanno, directeur du Industrial Relations Center de l'Université du Minnesota et Charles J. Coleman de l'Université Rutgers (Camden). 